\title{
Optimalisasi Pesan Dalam Buku Edukasi Pasien Diabetes Melitus Melalui Komunikasi Visual
}

\author{
${ }^{1}$ Tegar Andito, ${ }^{2}$ Martanty Aditya \\ ${ }^{1}$ Program Animasi Fakultas Media Rekam Institut Seni Indonesia Yogyakarta \\ ${ }^{2}$ Program Studi Farmasi Fakultas Sains dan Teknologi Universitas Ma Chung \\ ${ }^{1}$ tegarandito@isi.ac.id, ${ }^{2}$ martanty.aditya@machung.ac.id
}

\begin{abstract}
The limited number of healthcare personels affects failure on theraphy. In diabetes mellitus patients accellerates complication risks of micro or macrovascular so constant monitoring must be done. Most diabetes mellitus victims begins their diseases at age 45 or older which their cognitive abilities degrade but education is important for diabetes patients. Most healthcare personels educate their patients verbally. With cognitive abilities degradation of diabetes patients, verbal communication becomes less effective. To overcome this communication problem, the best way is to communicate with less verbally but more visually. Visual communication in this case becomes an effective communication alternative to deliver educational messages which is easier to understand and minimize communication bias. This booklet design hopefully overcomes existing communication barrier in order to improves life quality of patients.
\end{abstract}

Keywords: Visual Communication; Health; Booklet; Design; Diabetes Mellitus

\section{PENDAHULUAN}

Laporan hasil evaluasi retrospektif di farmasi komunitas, penyebab kegagalan terapi diantaranya adalah ketidakcukupan jumlah farmasis dalam memberikan pelayanan kefarmasian termasuk di dalamnya adalah konseling, informasi dan edukasi (KIE)(Pervanas, Revel, dan Alotaibi 2015). Bagi penderita diabetes kepatuhan terapi sangat diperlukan baik secara farmakologi dan non farmakologi. Pada kenyataannya kepatuhan menjadi hal yang sulit, penyebabnya antara lain usia, kurangnya informasi, persepsi dan lamanya penyakit, kompleksitas dari regimen dosis, politerapi, faktor psikologi, keamanan serta biaya (Garcia-Perez et al. 2013). Banyak penelitian membuktikan bahwa edukasi merupakan bagian penting yang bertujuan untuk meningkatkan kognitif pasien sehingga menimbulkan persepsi yang positif yang kemudian akan mendukung perubahan perilaku ke arah yang positif. Disinilah peran dari tenaga kesehatan untuk mendukung pasien ke tahap selanjutnya yaitu persiapan sampai dengan melakukan aksi (Bartholomew 2006; Glanz K 2008; Odgen 2007). Komunikasi visual dipilih untuk mengatasi hambatan yang dialami oleh tenaga kesehatan khususnya farmasi di komunitas agar dapat tetap mendampingi pasien. komunikasi visual lebih unggul karena materi edukasi menjadi lebih menarik, hal ini disebabkan adanya pengelolaan elemen yang terdiri atas ilustrasi, 
huruf dan tipografi, warna komposisi dan layout (Tinarbuko 2009, 24).

\section{Pembahasan Penelitian}

Hasil survey yang dilakukan pada klinik nirlaba Santo Andreas Malang di wilayah Malang menunjukan data demografi sebagai berikut:

\section{Usia}

Pasien yang menderita diabetes bervariasi dan dimulai pada usia diatas 40 tahun sampai dengan pasien geriatrik. Hasil penelitian menunjukkan adanya perubahan gaya berkomunikasi pada pasien dengan usia lanjut atau diatas 65 tahun, yaitu $42 \%$ dilaporkan kendala dengan pendengaran, $26 \%$ dengan menulis dan $7 \%$ dengan penggunaan telepon. Selain itu untuk meningkatkan pemahaman pasien terdapat beberapa hal yang bisa dilakukan antara lain dengan menggunakan gambar atau model untuk mengurangi distraksi dan selain itu untuk lebih menyederhanakan informasi. Hasil riset kesehatan dasar (Badan Penelitian dan Pengembangan Kesehatan Kementrian Kesehatan RI 2013) menunjukkan gejala diabetes meningkat dengan bertambahnya usia.

\section{Tingkat pendidikan}

Tingkat pendidikan juga memengaruhi dimana prevalensi lebih tinggi pada tingkat pendidikan yang tinggi dan kuntil indeks kepemilikan yang tinggi (Badan Penelitian dan Pengembangan Kesehatan Kementrian Kesehatan RI 2013).

\section{Tingkat pengetahuan}

Desain komunikasi visual menjembatani dalam memberikan edukasi pada pasien dengan diabetes. Hal ini disebabkan karena adanya penurunan kemampuan kognitif pada pasien yang mengalami diabetes. Adanya penurunan kognitif disebabkan beberapa faktor antara lain kondisi hiperglikemia yang menginduksi kerusakan mikrovaskular, kerusakan makrovaskular, hipoglikemia, tidak tersedianya C-peptida dan adanya resistensi insulin (Christopher T dan Elizabeth R 2008).

Disinilah peran penting dari edukasi untuk mencegah terjadinya hipoglikemia dan hiperglikemia sehingga mengurangi terjadinya komplikasi mikro dan makrovaskular yang makin memperparah kemampuan kognitif.

\section{Edukasi gaya hidup}

Bagi banyak pasien diabetes, tantangan terbesar pada perencanaan terapi adalah 
mencari tahu apa yang sebaiknya dikonsumsi. Pemilihan jenis makanan akan memengaruhi kadar insulin dalam darah. Contohnya adalah penggunaan nasi putih dapat menyebabkan peningkatan gula darah secara drastis dibandingkan dengan nasi merah atau coklat. Konsumsi buah juga sangat dianjurkan namun buah yang tepat. Konsumsi buah tropis dalam jumlah berlebih dapat menyebabkan peningkatan kadar gula darah lebih tinggi dibandingkan buah non musiman. Sedangkan pada olahraga menjadi hal penting karena bertujuan untuk meningkatkan sensitivitas insulin. Dalam hal ini olahraga yang disarankan adalah yang bersifat menenangkan karena olahraga yang menimbulkan stress akan meningkatkan kadar gula darah. Olahraga yang terlalu keras dapat menyebabkan penurunan kalori secara drastis dan memberikan efek hipoglikemia. Keadaan hipoglikemia dapat memperparah kondisi pasien (American Diabetes Association 2016).

\section{Kepatuhan}

Kepatuhan menjadi hal yang penting dalam menurunkan tingkat kejadian komplikasi mikrovaskular dan makrovaskular. Langkah yang perlu dilakukan adalah menilai kepatuhan, dalam hal ini buku tersebut dapat menjadi panduan bagi tenaga kesehatan dalam menilai kepatuhan. hal ini dapat diketahui dari daftar pemakaian obat. Mengetahui hambatan yang terjadi melalui penilaian dan evaluasi diri sendiri dari pasien tersebut melalui pertanyaan yang bertujuan untuk mengeksplorasi keinginan pasien dalam mencapai target terapi (American Diabetes Association 2016).

\section{Penggunaan obat-obatan}

Riwayat penggunaan obat juga menjadi faktor penting, hal ini karena pengunaan senyawa steroid, diuretic tiazid dna antpsikotik atipikal dapat meningkatkan efek hiperglikemia (American Diabetes Association 2016).

\section{Desain Grafis Buklet Edukasi Pasien Diabetes Melitus}

Tujuan perancangan buku ini adalah mengatasi keterbatasan tenaga kesehatan dalam memantau kondisi pasien diabetes melitus. Di dalam buku ini terdapat sejumlah isian yang dapat diisi sendiri oleh pasien dan tenaga medis mengenai kondisi kesehatan pasien yang bersangkutan di samping berbagai penjelasan dan anjuran tenaga kesehatan yang sebaiknya dilakukan oleh pasien diabetes melitus. Diharapkan melalui buklet ini pasien dapat memantau dan 
mendokumentasikan sendiri perkembangan kesehatannya sehingga ketika check up kesehatan dilakukan, tenaga medis dapat dengan mudah melihat perkembangan kondisi pasien yang telah terdokumentasi dan dapat memberikan tindakan-tindakan medis yang tepat dan rekomendasi-rekomendasi yang diperlukan.

Menurut Frascara, sasaran dari desain komunikasi visual bukanlah sekedar pembuatan sebuah wujud grafis, namun penciptaan sebuah komunikasi yang efektif darinya. Hal ini dapat dilihat pula dari istilah "desain komunikasi visual" sendiri yang terdiri dari tiga elemen, yakni metode (desain), tujuan (komunikasi), dan medium (visi/penglihatan) (Frascara 2004, 4). Desain grafis yang merupakan salah satu cabang dari desain komunikasi visual memiliki tujuan untuk memecahkan masalah komunikasi secara grafis.

Target audiens dari buklet ini adalah penderita diabetes melitus di mana sebagian penderitanya memiliki disfungsi kognitif sehingga memiliki kesulitan dalam menangkap komunikasi secara verbal. Penggunaan buklet edukasi untuk pasien diabetes melitus bermanfaat untuk mengatasi keterbatasan tenaga kesehatan dalam memantau kondisi pasien, namun penyampaian secara verbal saja melalui buklet dapat berisiko menimbulkan kesalahpahaman bagi audiens yang memiliki disfungsi kognitif. Komunikasi secara visual bermanfaat untuk mengatasi komunikasi verbal yang terhambat akibat disfungsi kognitif pasien diabetes melitus karena penyampaian pesan visual lebih mudah dan cepat dipahami dibandingkan dengan pesan verbal atau tertulis.

Hambatan komunikasi yang mungkin terjadi dalam perancangan buklet ini adalah adanya disfungsi kognitif pada target audiens. Untuk mengatasi itu, visualisasi yang ada berusaha ditampilkan secara eksplisit dan menghindari konotasi dan metafora.

Pemilihan huruf untuk keperluan informasi direncanakan dengan mempertimbangkan kemungkinankemungkinan yang terjadi pada penderita diabetes melitus. Beberapa penderita diabetes melitus yang tidak terkontrol gula darahnya memiliki kemungkinan gangguan penglihatan berupa rabun. Studi dilakukan menggunakan berbagai jenis huruf mulai dari serif, sans serif, dan script. Tujuan dari pemilihan font ini adalah memilih karakter huruf yang tepat yang legible dan dapat dipahami orang yang menderita gangguan kognitif dan gangguan penglihatan berupa rabun. 


\section{Visualisasi Buklet Edukasi}

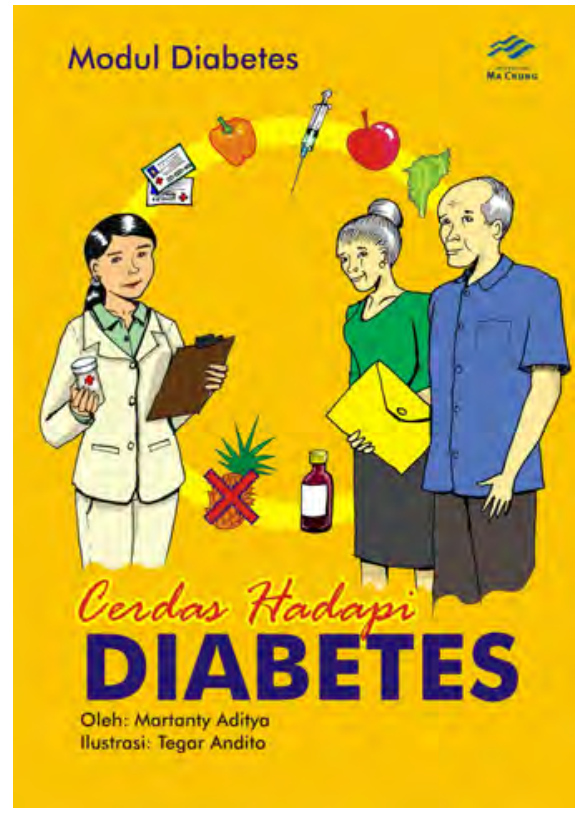

Gambar 1 Sampul buku edukasi pasien diabetes melitus menampilkan tenaga medis, pria-wanita setengah baya, dan visual obat-obatan, dan makanan yang dianjurkan maupun tidak bagi penderita diabetes melitus



Gambar 2 Isian data pasien menampilkan perawat. Sosok perawat ditampilkan karena di rumah sakit maupun poliklinik, perawat juga ditugaskan untuk mengumpulkan data-data awal pasien sebelum dilanjutkan ke pemeriksaan oleh dokter



Gambar 3 Lanjutan isian data pasien. Kali ini ditampilkan riwayat yang berkaitan dengan kesehatan pasien. Pada isian riwayat alergi ditampilkan sejumlah obyek yang sering menjadi pemicu alergi pada masyarakat pada umumnya

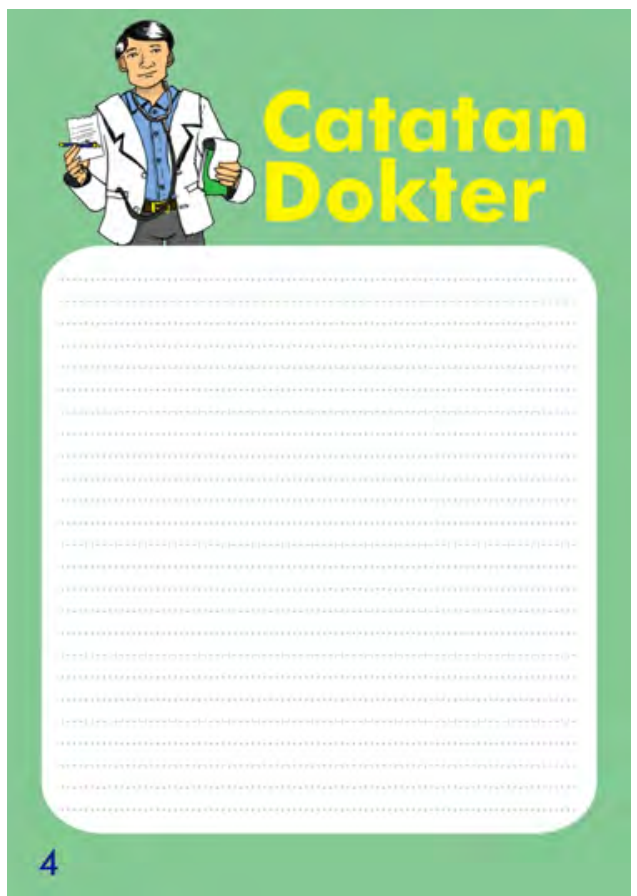

Gambar 4 isian catatan dokter. bagian ini diisi oleh dokter. dapat berupa diagnosis atau anjuran-anjuran dari dokter mengenai apa yang sebaiknya dilakukan oleh pasien terhadap hal-hal yang berkaitan dengan penyakit diabetes melitus 


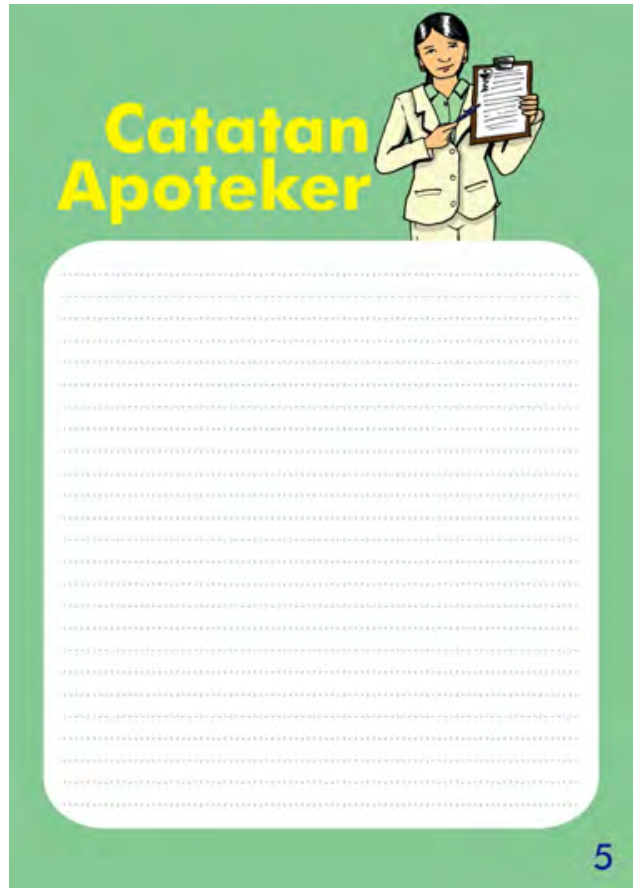

Gambar 5 isian catatan apoteker. bagian ini diisi oleh apoteker. dapat berupa anjuran-anjuran obat berdasarkan diagnosis dokter.

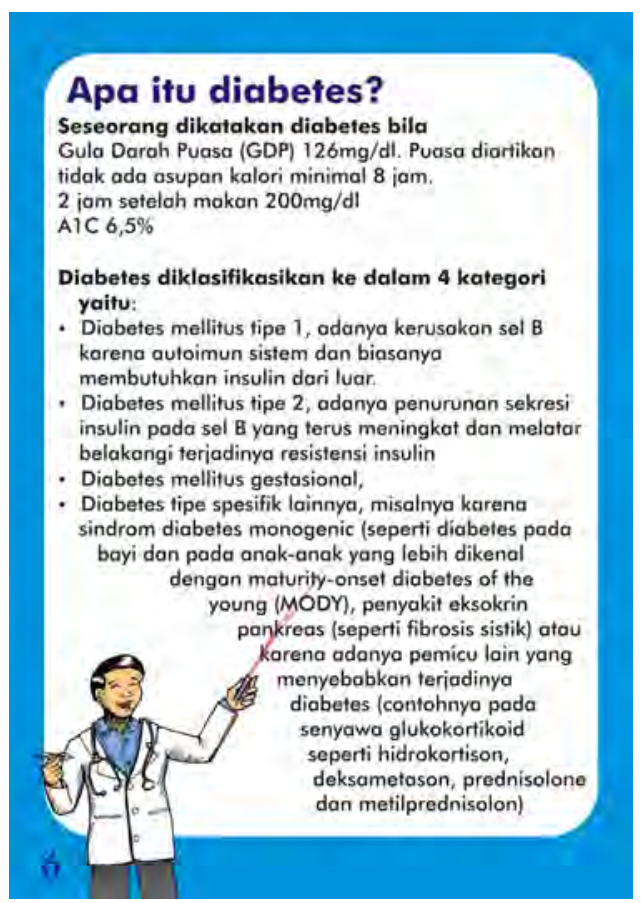

Gambar 6 penjelasan mengenai diabetes melitus. font dibuat lebih besar untuk mengantisipasi jika dibaca oleh pasien yang memiliki gangguan penglihatan

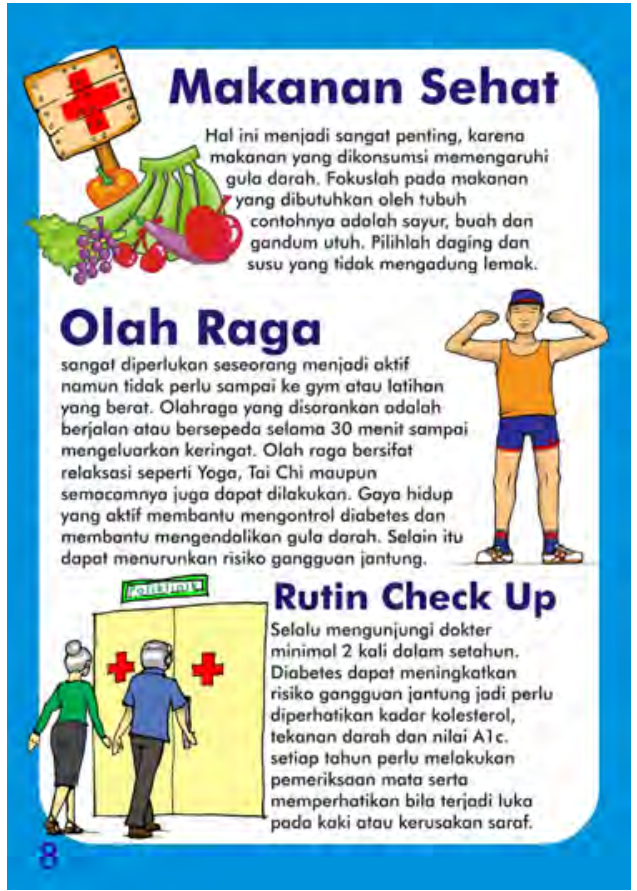

Gambar 7 anjuran-anjuran bagi pasien diabetes melitus. Ilustrasi bukan sekedar hiasan, namun juga menampilkan mengenai jenis-jenis buah dan sayuran yang dianjurkan serta macam olah raga yang dianjurkan dalam hal ini ditampilkan olah raga yang berupa relaksasi

\section{KESIMPULAN}

Diabetes melitus merupakan kondisi yang memerlukan penanganan seumur hidup dan umumnya terjadi pada usia lebih dari 45 tahun. Dalam pelaksanaannya hal ini menjadi sulit karena keterbatasan tenaga kesehatan dan pasien baik dari sisi waktu maupun kemampuan kognitif yang semakin menurun. Perancangan buklet Cerdas Hadapi Diabetes ini diharapkan dapat mengatasi hambatan komunikasi yang terjadi baik dari sisi pasien dengan kemampuan kognitifnya yang menurun serta minimnya waktu dari tenaga 
kesehatan untuk selalu memantau kondisi pasien.

\section{Ucapan Terima Kasih}

Ucapan terima kasih disampaikan kepada Kementrian Riset, Teknologi, dan Pendidikan Tinggi Republik Indonesia melalui program hibah penelitian dosen pemula tahun pendanaan 2017.

\section{DAFTAR PUSTAKA}

[1] American Diabetes Association. 2016. "Standards of Medical Care in Diabetes." Diabetes Care 39(Supplement 1): S1-112.

[2] Badan Penelitian dan Pengembangan Kesehatan Kementrian Kesehatan RI. 2013. Riset Kesehatan Dasar. Jakarta.

[3] Bartholomew, L Kay. 2006. Planning Health Promotion Programs: An Intervention Mapping Approach. San Francisco: Jossey Bass a Wiley Imprint.

[4] Christopher T, Kodl, dan Seaquist Elizabeth R. 2008. "Cognitive Dysfunction and Diabetes Mellitus." Endocrine Reviews 29(4): 494-511.

[5] Frascara, Jorge. 2004. Communication Design: Principles, Methods, and Practice. New York: Allworth Press.

[6] Garcia-Perez, Luis-Emilio et al. 2013. "Adherence to Therapies in Patients with Type 2 Diabetes." Diabetes Therapy 4(2): 175-94.

[7] Glanz K, Rimer BK. 2008. Health Behavior and Health Eduation: Theory, Research and Practice. 4th Editio. San Francisco: John Wiley \& Sons.

[8] Odgen, Jane. 2007. Health Psychology. 4th ed. New York: McGraw Hill.

[9] Pervanas, Helen C, Ngoc Revel, dan Amal F Alotaibi. 2015. "Evaluation of
Medication Error in Community Pharmacy Settings: A Retrospective Report." Journal of Pharmacy Technology 32(2): 71-74.

[10] Tinarbuko, Sumbo. 2009. Semiotika Komunikasi Visual: Edisi Revisi. Yogyakarta: Jalasutra. 